\title{
Transducin-Like Enhancer Protein 1
}

National Cancer Institute

\section{Source}

National Cancer Institute. Transducin-Like Enhancer Protein 1. NCI Thesaurus. Code C104862.

Transducin-like enhancer protein 1 (770 aa, $\sim 83 \mathrm{kDa})$ is encoded by the human TLE1 gene. This protein is involved in transcriptional regulation. 